\title{
Friedel-Crafts Polyketones: Synthesis, Characterization and Antimicrobial Properties of Unsaturated Polyketones and Copolyketones Based on Difurfurylidene Cycloheptanone
}

\author{
Nayef S. Al-Muaikel \\ Chemistry Department, College of Pharmacy, Aljouf University, Al Jouf, P.O. Box 643, Sakaka, Al Jouf, Saudi Arabia \\ Correspondence should be addressed to Nayef S. Al-Muaikel,n_almuaikel@hotmail.com \\ Received 3 April 2011; Accepted 17 May 2011 \\ Academic Editor: Jan-Chan Huang \\ Copyright (c) 2011 Nayef S. Al-Muaikel. This is an open access article distributed under the Creative Commons Attribution License, \\ which permits unrestricted use, distribution, and reproduction in any medium, provided the original work is properly cited.

\begin{abstract}
A new type of unsaturated polyketones and copolyketones having cycloheptanone moiety in a p-conjugated main chain were synthesized via Friedel-Crafts reaction through the polymerization of the monomer: 2,7-bis furfurylidene cycloheptanone I with different diacid chlorides. The model compound was synthesized by reacting I with benzoyl chloride and characterized by ${ }^{1} \mathrm{H}-\mathrm{NMR}, \mathrm{IR}$, and elemental analyses. The polyketones and copolyketones were soluble easily in protic solvents like $\mathrm{H}_{2} \mathrm{SO}_{4}$ and trifluoroacetic acid. The thermal properties of these polyketones and copolyketones were evaluated and correlated to their structural units by TGA and DSC measurements. The crystallinity of some polymers was tested by X-ray analyses; also the morphological properties of selected examples of poly and copolyketones were detected by SEM. All the polyketones were tested for their biological activity against bacteria, fungi, and yeast. It was observed that the majority of the polyketones and its copolymers synthesized can be used as antibacterial and antifungal agents.
\end{abstract}

\section{Introduction}

Polyketones represent a new class of potential engineering thermoplastics. Their property set is positioned in the area of polyamides and polyacetals. They are characterized by their stiffness, high melting temperature, and resistance to water and moisture. In addition, one should also mention chemical resistance, stability at hydrolysis conditions, impact toughness, flame resistance without additives containing halides or red phosphor, and short cycle times in injection molding [1-3]. Friedel-Crafts polymers formed on polycondensation of $4,4^{\prime}$-dichloromethyldiphenyl ether (DDE) with benzene, toluene, isomeric chlorotoluenes and xylenes, phenol, and isomeric cresols have been reported [4-6]. Recently, a considerable amount of research effort has concentrated on the synthesis of polyketones via Friedel-Crafts reaction [7-11].

During the last decade an extensive work was carried out towards the prevention of biological degradation of useful materials such as textile fibers, food packaging materials, paints, marine coatings, electrical insulation and pharmaceutical materials using certain polymeric systems having biocidal properties [12-14]. It was, therefore, thought appropriate to synthesize the polyketones and copolyketones containing cycloheptanone moiety and examine their biocidal properties against Aspergillus flavus, Aspergillus niger, Candida albicans, Geotrichum candidum, Trichophyton rubrum, Escherichia coli, Pseudomonas aeruginosa, and Staphylococcus aureus.

\section{Experimental}

\subsection{Materials}

2.1.1. Reagents. Furfural (Fluka, Germany) was freshly distilled at b.p. $162^{\circ} \mathrm{C}$. Cycloheptanone (Merck) was used without purification. Benzoyl chloride (Aldrich, Seelze, Germany) was used as purchased. Terephthaloyl chloride and isophthaloyl chloride (Aldrich, Seelze, Germany) were recrystallized twice from n-hexane (m.p $83-84^{\circ} \mathrm{C}$ and $40^{\circ} \mathrm{C}$ resp.). Adipoyl and sebacoyl dichlorides [15] were freshly distilled at $125^{\circ} \mathrm{C} / 11$ Torr and at $182^{\circ} \mathrm{C} / 16$ Torr, respectively were used. Anhydrous aluminum chloride and sodium 
TABLe 1: Elemental analyses, inherent viscosity, yield and color of polyketones IVa-d and coployketones V and VI.

\begin{tabular}{llccccccc}
\hline $\begin{array}{l}\text { Polymer } \\
\text { Code }\end{array}$ & $\begin{array}{l}\text { Repeating } \\
\text { unit }\end{array}$ & Calcd. & Found & Calcd. & Found & $\begin{array}{c}\eta_{\text {Inh }} \\
(\mathrm{dI} / \mathrm{g})\end{array}$ & $\begin{array}{c}\text { Yield\% } \\
\text { Appearanc of } \\
\text { polymer }\end{array}$ \\
\hline IVa & $\mathrm{C}_{25} \mathrm{H}_{18} \mathrm{O}_{5}$ & 75.38 & 74.43 & 4.52 & 4.26 & 0.37 & 68 & Powder-yellow \\
IVb & $\mathrm{C}_{25} \mathrm{H}_{18} \mathrm{O}_{5}$ & 75.38 & 74.92 & 4.52 & 4.13 & 0.42 & 73 & Powder-yellow \\
IVc & $\mathrm{C}_{23} \mathrm{H}_{22} \mathrm{O}_{5}$ & 73.02 & 72.58 & 5.82 & 5.58 & 0.56 & 76 & Powder-yellow \\
IVd & $\mathrm{C}_{27} \mathrm{H}_{30} \mathrm{O}_{5}$ & 74.65 & 73.14 & 6.91 & 6.72 & 0.63 & 69 & Powder-yellow \\
V & $\mathrm{C}_{52} \mathrm{H}_{36} \mathrm{O}_{8}$ & 79.19 & 77.87 & 4.56 & 4.41 & 0.52 & 85 & Powder-yellow \\
VI & $\mathrm{C}_{48} \mathrm{H}_{44} \mathrm{O}_{8}$ & 77.01 & 76.72 & 5.88 & 5.32 & 0.46 & 81 & Powder-yellow \\
\hline
\end{tabular}

${ }^{*} \eta$ Inherent viscosity measured in $\mathrm{H}_{2} \mathrm{SO}_{4}$ at $25^{\circ} \mathrm{C}$.

hydroxide (BDH, Leicestershire, England) were of analytical grade and were used as received.

2.1.2. Solvents. Methanol, $99.8 \%$, Ethanol, $99.9 \%$ (Hayman, Eastways Withan, England), acetone and N,N-dimethyl formamide (DMF), (BDH, Leicestershire, England), NMethyl-2-pyrrolidone (NMP) and benzene (Aldrich, Seelze, Germany) were extra pure solvents and were used as received. Carbon disulphide (Aldrich, Seelze, Germany) was a guaranteed reagent, dried over calcium hydride for $24 \mathrm{~h}$, and followed by distillation under reduced pressure.

\subsection{Methods}

\subsubsection{Monomer Synthesis}

Synthesis of 2,7-bis furfurylidene Cycloheptanone I. A mixture of 0.1 mole cycloheptanone and 0.2 mole of furfural in warm ethanol was stirred, and few drops of $\mathrm{NaOH}(20 \%$ conc.) were added. The reaction mixture was stirred at room temperature for $1 \mathrm{hr}$, and the resulting solid was collected by filtration, washed with cold water, dried and recrystallized from ethanol, as yellow needles; yield 95\%, m.p $166^{\circ} \mathrm{C}$. Calculated for $\mathrm{C}_{17} \mathrm{H}_{16} \mathrm{O}_{3}$ : C, 76.69; $\mathrm{H}, 6.02 \%$. Found: $\mathrm{C}$, 76.53; H, 5.85\%. IR ( $\left.\mathrm{KBr}, \mathrm{cm}^{-1}\right)$ : at $1600(\mathrm{~s}, \mathrm{C}=\mathrm{C})$, at 1660 (s, $\mathrm{C}=\mathrm{O}) .{ }^{1} \mathrm{H}-\mathrm{NMR}\left(\mathrm{CDCl}_{3}, \mathrm{ppm}\right)$, at $7.0-8.0(\mathrm{~m}, 6 \mathrm{H}$ of furfuryl moieties and $2 \mathrm{H}$ of $2 \mathrm{CH}=\mathrm{C})$; at $2.2-2.5\left(\mathrm{~d}, 4 \mathrm{H}\right.$ of $\left.2 \mathrm{CH}_{2}\right)$; at 1.8-2.1 (d, $4 \mathrm{H}$ of middle $2 \mathrm{CH}_{2}$ of cycloheptanone).

Synthesis of 2,7-bis(benzylidene)cycloheptanone II. This monomer was prepared as described previously [16].

2.2.2. Synthesis of Model Compound III. In a three necked flask equipped with a condenser, dry nitrogen inlet and outlet, and a dropper, a mixture of 1 mmole of monomer I suspended in $40 \mathrm{~mL}$ of carbon disulphide and 2 mmole of benzoyl chloride were introduced. A 20 mmole of anhydrous aluminum chloride was added portion wise to the solution. The solution was stirred for $24 \mathrm{hrs}$ at $25^{\circ} \mathrm{C}$, and the separated solid product was filtered off washed with water dried in vacuum at room temperature. An analytical sample was obtained by recrystallization from benzene in yellow needles, yield $75 \%$, m.p $219^{\circ} \mathrm{C}$. Calculated for $\mathrm{C}_{31} \mathrm{H}_{24} \mathrm{O}_{5}$ : C, 78.15; $\mathrm{H}$, 5.04; \%. Found: C, 77.76; H, 5.01\%. IR $\left(\mathrm{KBr}, \mathrm{cm}^{-1}\right)$ : at 1670 ( $\mathrm{C}=\mathrm{O}$ of cycloheptanone), at 1700 ( $\mathrm{C}=\mathrm{O}$ of benzoyl group), at 1600 (C=C group). ${ }^{1} \mathrm{H}-\mathrm{NMR}$ (DMSO- $\left.\mathrm{d}_{6}, \mathrm{ppm}\right)$, at 7.2-8.5 $(\mathrm{m}, 4 \mathrm{H}$, furfuryl moiety, $10 \mathrm{H} \mathrm{Ar}-\mathrm{H}$, and $2 \mathrm{H}$ of $2 \mathrm{CH}=\mathrm{C})$, at $2.2-2.5\left(\mathrm{~d}, 4 \mathrm{H}\right.$ of $\left.2 \mathrm{CH}_{2}\right)$; at $1.8-2.1\left(\mathrm{~d}, 4 \mathrm{H}\right.$ of middle $2 \mathrm{CH}_{2}$ of cycloheptanone).

2.2.3. Synthesis of Polyketones IVa-d. Friedel-Crafts method was applied for the preparation of all the polymers. Typically, in a three necked flask equipped with a condenser, dry nitrogen inlet and outlet, and a dropper, a mixture of 6 mmole $(1.596 \mathrm{~g})$ of monomer I and $1.218 \mathrm{~g}$ ( 6 mmole $)$ of isophthaloyl chloride in $25 \mathrm{~mL}$ of dry carbon disulphide were introduced. The flask was purged with nitrogen while stirring and a $2.66 \mathrm{~g}$ ( 20 mmole) of aluminum chloride was added during the nitrogen flash. The reddish brown reaction mixture was stirred for $24 \mathrm{hrs}$ then it was filtered, off and the separated product was triturated three times with a large excess of methanol. The powdery material was again filtered off, washing with water, methanol, and acetone, and dried under reduced pressure $(1 \mathrm{mmHg})$ at $70^{\circ} \mathrm{C}$ for 2 days. This method was applied for the preparation of other polyketones; whose yields, elemental analyses, viscosity, and colors are listed in Table 1.

2.2.4. Synthesis of Copolyketones V and VI. The same method, which applied in the synthesis of the polyketones, was also applied in the synthesis of the copolyketones.

Typically, in a three necked flask equipped with a condenser, dry nitrogen inlet and outlet, and a dropper, a mixture of $0.798 \mathrm{~g}$ ( $3 \mathrm{mmole}), 2,7$-bis furfurylidene cycloheptanone I and $0.864 \mathrm{~g}$ ( 3 mmole) of 2,7-bis(benzylidene)cycloheptanone II and $1.208 \mathrm{~g}(6 \mathrm{mmole})$ of terephthaloyl chloride, and $50 \mathrm{~mL}$ of dry carbon disulphide were introduced. The flask was purged with nitrogen while stirring, and $2.66 \mathrm{~g}$ ( $20 \mathrm{mmole}$ ) of aluminum chloride was added during the nitrogen flash. The reddish brown reaction mixture was stirred for $24 \mathrm{hrs}$ then it was filtered off, and the separated product was triturated three times with a large excess of methanol. The powdery material was again filtered off, washing with water, methanol, and acetone and dried under reduced pressure $(1 \mathrm{mmHg})$ at $70^{\circ} \mathrm{C}$ for 2 days. This method was applied for the synthesis of copolyketone VI; whose yield, elemental analysis, viscosity, and colors are also listed in Table 1. 


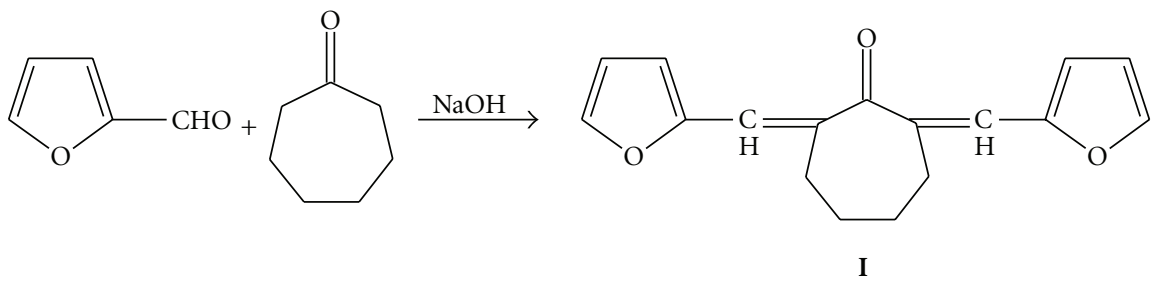

Scheme 1: Synthesis of 2,7-bis furfurylidene cycloheptanone I.

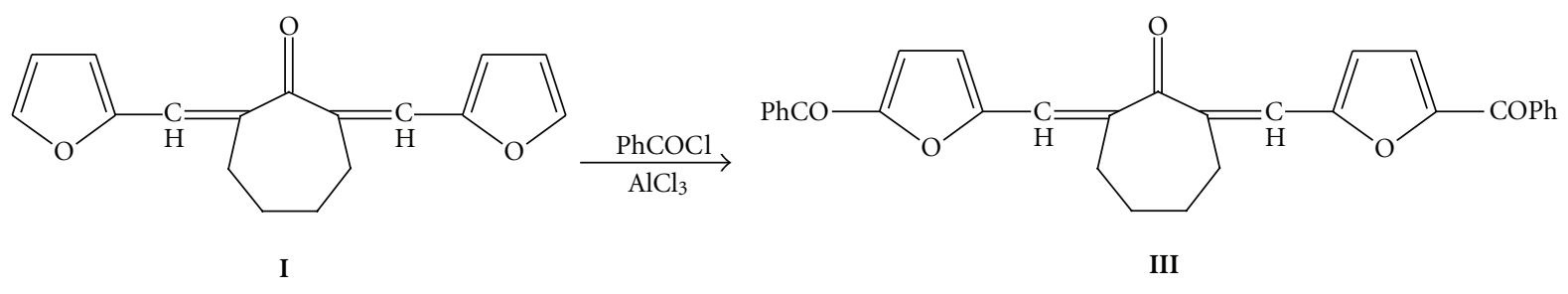

Scheme 2: Synthesis of model compound III.

Polymer Identification. Infrared spectra of the prepared polymers were measured on a Nicolet 6700 FT-IR Thermo Fisher Scientific Incorporation. (USA). The powder samples were of similar weight and mixed with $\mathrm{KBr}$. All spectra were recorded within the wave number range of $4000-400 \mathrm{~cm}^{-1}$ at $25^{\circ} \mathrm{C}$. Elemental analyses of the prepared monomers, model compound, and polymers were performed at the Micro Analytical Unit, Assiut University, Egypt.

\section{Polymer Characterization}

Viscosity. Inherent viscosity measurements were carried out on $0.5 \%$ solutions of the polymers in NMP at $30^{\circ} \mathrm{C}$ using a suspended-level Ubbelohde viscometer with negligible kinetic energy correction. Flow times were measured at five different concentrations of the polymer sample. All the plots obtained were linear. Inherent viscosity was determined by usual extrapolation of gsp/c to zero concentration and expressed in deciliter per gram $\left(\mathrm{dL} \mathrm{g}^{-1}\right)$.

Solubility. The solubility of polymers in various solvents such as DMF, DMSO, and NMP was determined at room temperature $\left(30^{\circ} \mathrm{C}\right)$. It was performed by gradual addition of the polymer to the solvent and stirred well till saturation. The maximum solubility of the polymers were calculated as percent weight of the polymer per hundred milliliter of solvent $(\% \mathrm{w} / \mathrm{v})$.

Scanning Electron Microscopy Measurements. The morphology of polyketone A as an example was examined by scanning electron microscopy (SEM) using a Jeol JSM-5400 LV instrument.

Thermogravimetric Analysis. Thermogravimetric analysis (TGA) curves were recorded on a Shimadzu TGA-50 H in air atmosphere at a heating rate of $10^{\circ} \mathrm{C} \mathrm{min}^{-1}$ and a heating range from room temperature to $700^{\circ} \mathrm{C}$. The sample weights ranged from 3 to $5 \mathrm{mg}$, and the gas flow rate was $30 \mathrm{~mL} \mathrm{~min}^{-1}$.

Antimicrobial Properties. The antimicrobial screening of polyketones and copolyketones (IV-a-d, V, VI ) were performed using the standard agar diffusion method, against different organisms (fungal and bacterial species) including: Aspergillus flavus, Aspergillus niger, Candida albicans, Geotrichum candidum, Trichophyton rubrum, Escherichia coli, Pseudomonas aeruginosa, and Staphylococcus aureus. The fungal species were maintained on sabourand dextrose agar (SDA) whereas the bacterial species were maintained on nutrient agar (NA).

\section{Results and Discussion}

3.1. Synthesis of Monomer I. 2,7-bis furfurylidene cycloheptanone I monomer was synthesized in good yields by the basic catalyzed condensation of two moles of furfural with one mole of cycloheptanone, as shown in Scheme 1.

3.2. Synthesis of Model Compound III. Before attempting the polymerization, model compound was prepared by the reaction of monomer I with two equivalents benzoyl chloride. A typical reaction is depicted in Scheme 2.

3.3. Synthesis of Polyketones IVa-d. In order to determine an adequate catalyst for the synthesis of polyketones based on furfurylidene cyclopentanone in the main chain, FriedelCrafts polycondensation of 2,7-bis furfurylidene cycloheptanone I with terephthaloyl chloride (as an example) (polymer IVb) was carried out in the presence of various Lewis acids such as $\mathrm{FeCl}_{3}, \mathrm{SbCl}_{5}$, and $\mathrm{AlCl}_{3}$. It appeared that anhydrous $\mathrm{AlCl}_{3}$ gave the best result with respect to yield and degree of polymerization. The favorable mole ratio of catalyst to each reactant was ca. 2.0. 

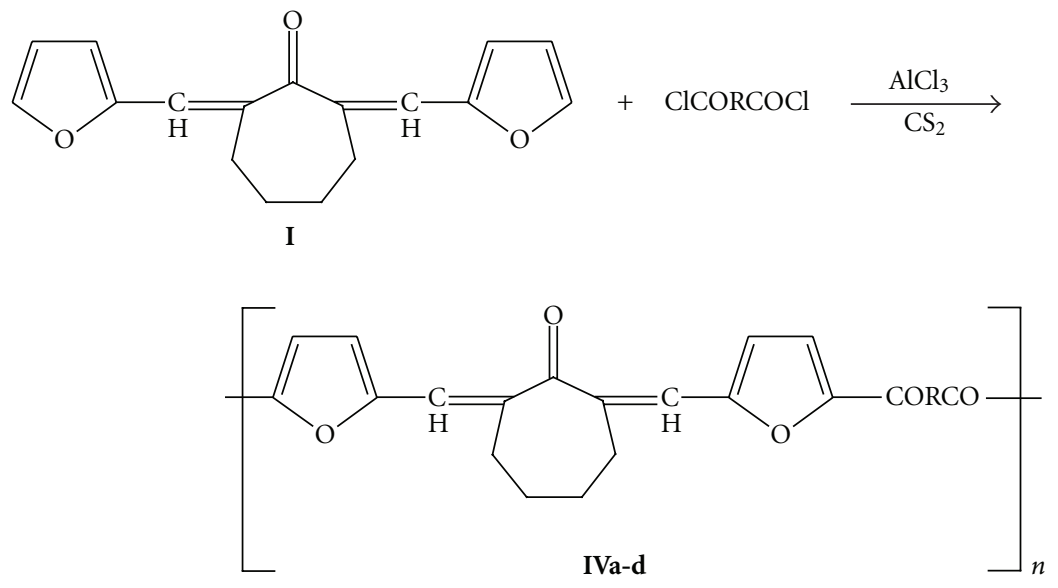

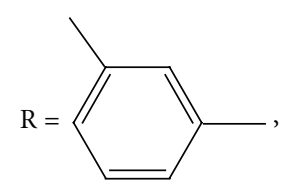

a

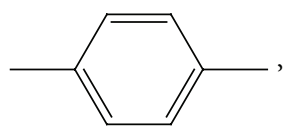

b

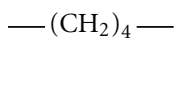

c

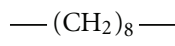

d

Scheme 3: Synthesis of polyketones IVa-d.<smiles>O=C1C(=Cc2ccco2)CCCCC1=Cc1ccco1</smiles>

I<smiles>O=C1C(=Cc2ccccc2)CCCC1=Cc1ccccc1</smiles>

II<smiles>CCC=C1CCCCC(=Cc2ccc(OC(=O)c3ccc(OC(=O)c4ccc(C=C5CCCCC(=Cc6ccc(C)o6)C5=O)o4)cc3)cc2)C1=O</smiles>

Scheme 4: Synthesis of copolyketone V.

On the basis of these results, Friedel-Crafts polycondensation of dicarbonyl chlorides including: isophthaloyl, terephthaloyl, adipoyl and sebacoyl dichlorides with 2,7-bis furfurylidene cycloheptanone I was carried out at room temperature for $24 \mathrm{hrs}$. These reactions are shown in Scheme 3.

3.4. Synthesis of Copolyketones $V$ and VI. Unreported copolyketones $\mathbf{V}$ and $\mathbf{V I}$ containing two different moieties for example bis furfurylidene cycloheptanone, and bisbenzylidene cycloheptanone in the polymer main chain. These two copolyketones were synthesized from the copolymerization of monomer I and monomer II with two different diacid chlorides, for example, terephthaloyl or adipoyl as shown in Schemes 4 and 5.

The polymerization and copolymerization reactions were carried out at room temperature in carbon disulphide as a 

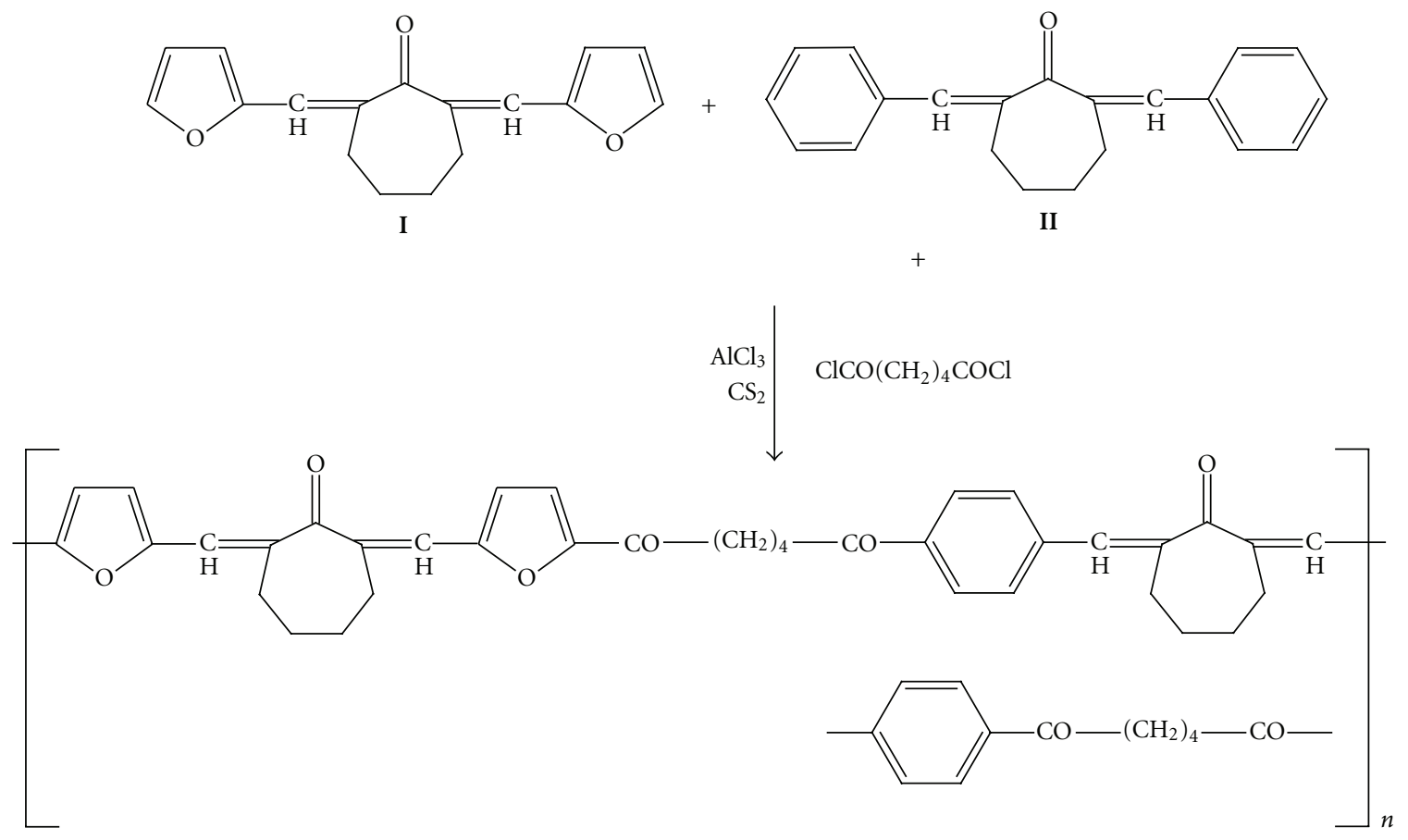

Scheme 5: Synthesis of copolyketone VI.

solvent and anhydrous aluminum chloride as a catalyst. The reaction times varied from 20 to $24 \mathrm{hr}$ and the polymers and copolymers were immediately isolated when the reaction mixtures were poured into methanol/water mixture, with yield in the range of $68-85 \%$. These polymers were characterized by elemental analysis, IR spectroscopy, solubility, viscometry, thermal analysis, and morphological properties. The elemental data of all the polymers and copolymers coincided with the characteristic repeating units (Table 1).

Spectral analyses in ( $\mathrm{KBr}$ disks) showed the appearance of new carbonyl absorption at $1690-1720 \mathrm{~cm}^{-1}$, characteristic for the $\mathrm{C}=\mathrm{O}$ of ketonic group besides the original $\mathrm{C}=\mathrm{O}$ of cycloheptanone at $1650-1670 \mathrm{~cm}^{-1}$, and at $\mathrm{C}=\mathrm{C}$ at $1595-$ $1610 \mathrm{~cm}^{-1}$. Other characteristic absorption peaks for the rest of the groups in the molecules were also present.

\subsection{Properties of the Polyketones IVa-d and Copolyketones} $V, V I$. The solubility characteristics of polyketones and copolyketones (IVa-d, V, VI) were tested in various solvents (Table 2) including: dimethylsulfoxide (DMSO), N,Ndimethylformamide (DMF), N-methylpyrrolidone (NMP), tetrahydrofuran (THF), methylene chloride, $\mathrm{CHCl}_{3}$-acetone $(1: 1)$, and concentrated sulphuric acid. It was found that all the polyketones and copolyketones dissolved readily in concentrated $\mathrm{H}_{2} \mathrm{SO}_{4}$ at room temperature giving deep red color due to the instability of the polymers. For halogenated solvents like $\mathrm{CH}_{2} \mathrm{Cl}_{2}$ and $\mathrm{CHCl}_{3}$-acetone mixture, polymers IVa-c and copolymers V, VI were partially soluble. More particularly, polymer IVd and copolymer VI (with $n=8$ or 4 resp.) showed good solubility in most organic solvents, due to the high flexibility of these polymers through the polymethylene spacers.
The morphology of the synthesized polyketone IVa in Figures 1(a) and 1(b) was examined by SEM (Jeol-SM-5400 LV instrument). The SEM sample was prepared by putting a fine powder of polyketone on a smooth surface of aluminum foil and coating it with gold-palladium alloy. The SEM (Camera) with Ilford film at an accelerating voltage of $15 \mathrm{kv}$ using a low-dose technique [17]. The SEM study of polyketone IVa in Figures 1(a) and 1(b) showed that the polymer had a polymorph globular and subglobular structures which (with magnification) the globular structure has a "cauliflower" appearance.

The thermal behavior of polyketones IVa,d and copolyketones V and VI were evaluated by thermogravimetric analysis (TGA) in air at a heating rate of $10^{\circ} \mathrm{C} / \mathrm{min}$. The thermographs of these polymers are given in Figure 2, also Table 3 gives the temperature of various percentages of weight loss. In Figure 2, TGA curves of polyketones IVa (as an example) show a small weight loss in the range $2-4 \%$ starting at $160^{\circ} \mathrm{C}$ until $200^{\circ} \mathrm{C}$, which may be attributed to loss of absorbed moisture and entrapped solvents. The thermographs also indicate the polymers decompose in two stages. The first stage between $205^{\circ} \mathrm{C}$ and $310^{\circ} \mathrm{C}$ depends upon the nature of the polyketones. This result is in good agreement with the decomposition of ketone-linkage observed by Swedo and Marvel [18]. The second stage of degradation of polyketones occurred between $330^{\circ} \mathrm{C}$ and $540^{\circ} \mathrm{C}$. The rate of degradation in the first stage is somewhat faster than in the second stage. A comparison of the $\mathrm{T}_{10}$ values of polyketones IVa,b containing aromatic moiety showed better thermal stability than others based on aliphatic IVc,d. For copoyketones V and VI, a small 
TABLE 2: Solubility characteristics of polyketones IVa-d and copolyketones V and VI.

\begin{tabular}{|c|c|c|c|c|c|c|c|}
\hline Polymer code & DMSO & $\mathrm{DMF}$ & NMP & $\begin{array}{c}\text { Chloroform } \\
\text { Acetone }(1: 1)\end{array}$ & THF & $\begin{array}{l}\text { Methylene } \\
\text { chloride }\end{array}$ & $\mathrm{H}_{2} \mathrm{SO}_{4}$ \\
\hline IVa & \pm & \pm & \pm & \pm & \pm & \pm & + \\
\hline IVb & \pm & \pm & \pm & \pm & \pm & - & + \\
\hline IVc & \pm & \pm & \pm & \pm & \pm & - & + \\
\hline IVd & + & + & \pm & + & \pm & \pm & + \\
\hline $\mathrm{V}$ & \pm & \pm & \pm & \pm & \pm & \pm & + \\
\hline VI & + & \pm & \pm & \pm & \pm & \pm & + \\
\hline
\end{tabular}

(+) Soluble at room temperature RT.

( \pm ) Partially soluble at RT.

(-) Insoluble.

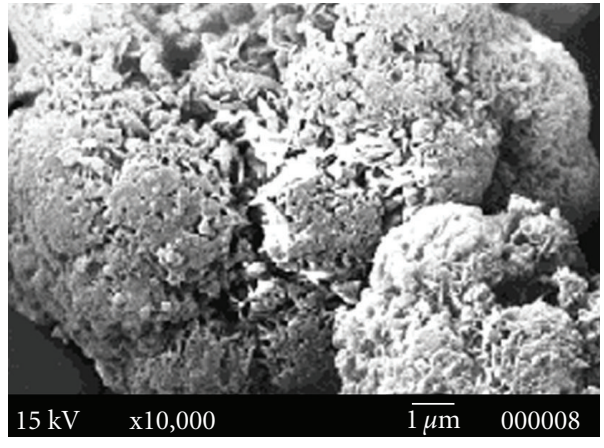

(a)

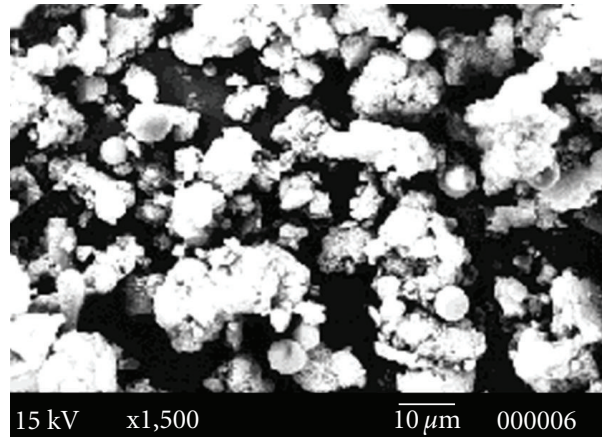

(b)

FIGURE 1: SEM image of polyketone IVa.

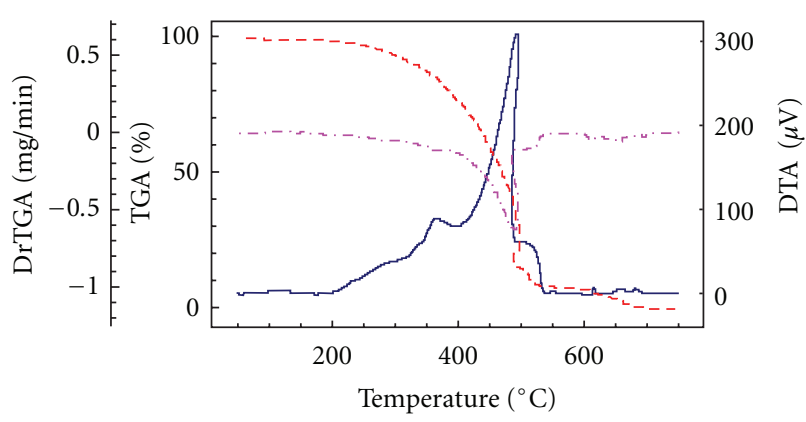

FIgURE 2: Thermogravimetric curves of polyketones IVa.

weight loss in the range $2-4 \%$ starting at $180^{\circ} \mathrm{C}$ until $220^{\circ} \mathrm{C}$, which may be attributed to loss of absorbed moisture and entrapped solvents. In contrary to the decomposition of the polyketones, the decomposition of copolyketones occurred in one step only, and the $\mathrm{T}_{10}$ values are in the range 350$370^{\circ} \mathrm{C}$. Moreover, the data indicated that the copolyketone V is more thermally stable than the copolyketone VI, and this may be attributed to the presence polymethylene groups $\left(\mathrm{CH}_{2}\right)_{4}$ in as flexible spacers in the polymer main chain in the later copolyketone, and this decreases the stability.
TABle 3: Thermal properties of Polyketones IVa-d and V, VI.

\begin{tabular}{lccccc}
\hline Polymer & \multicolumn{5}{c}{ Temperature $\left({ }^{\circ} \mathrm{C}\right)$ for various decomposition levels } \\
code & $10 \%$ & $20 \%$ & $30 \%$ & $40 \%$ & $50 \%$ \\
\hline IVa & 300 & 350 & 385 & 445 & 470 \\
IVb & 250 & 265 & 280 & 310 & 370 \\
IVc & 210 & 255 & 280 & 310 & 355 \\
IVd & 205 & 250 & 275 & 305 & 340 \\
V & 370 & 420 & 455 & 470 & 495 \\
VI & 350 & 405 & 435 & 440 & 470 \\
\hline
\end{tabular}

${ }^{*}$ Heating rate: $10^{\circ} \mathrm{C} \mathrm{min}^{-1}$.

Antimicrobial Screening. The antimicrobial screening of polyketones IVa-d and copolyketone $\mathbf{V}$ were performed using the standard agar diffusion method, against different organisms (fungal and bacterial species) including: Aspergillus flavus, Aspergillus niger, Candida albicans, Geotrichum candidum, Trichophyton rubrum, Escherichia coli, Pseudomonas aeruginosa, and Staphylococcus aureus.

The fungal species were maintained on sabourand dextrose agar (SDA) whereas the bacterial species were maintain on nutrient agar (NA). Similar inhibitory effects were obtained by several authors who dealt with antifungal and 
TABLE 4: Effect of polyketones IVa,c,d, and copolyketones V, VI on the growth of fungal and bacterial species.

\begin{tabular}{|c|c|c|c|c|c|c|}
\hline \multirow[t]{2}{*}{ Type of Organism } & \multicolumn{6}{|c|}{ Polyketone inhibition number zone ( $\mathrm{mm})$} \\
\hline & IVa & IVc & IVd & $\mathbf{V}$ & VI & Control \\
\hline Aspergillus niger & 11 & 8 & 10 & 0 & 8 & 19 \\
\hline Candida albicans & 0 & 0 & 0 & 0 & 0 & 30 \\
\hline Trichophyton rubrum & 15 & 18 & 0 & 0 & 8 & 23 \\
\hline Aspergillus flavus & 6 & 7 & 11 & 18 & 0 & 25 \\
\hline Escherichia coli & 0 & 0 & 0 & 0 & 0 & 26 \\
\hline Pseudomonas aeruginosa & 0 & 0 & 0 & 0 & 0 & 18 \\
\hline Geotrichum candidum & 0 & 10 & 21 & 9 & 8 & 32 \\
\hline $\begin{array}{l}\text { Staphylococcus } \\
\text { aureussome fungi, yeast, } \\
\text { and bacteria including: } \\
\text { Aspergillus niger, }\end{array}$ & 13 & 9 & 17 & 15 & 0 & 24 \\
\hline
\end{tabular}

Control: (antibacterial: chloramphenicol, antifungal: trosyd).

antibacterial activities of different polyketone derivatives. Patel and Patel [11] pointed out that chlorine containing polyketones exerted a very closed an inhibitory effect against some fungi, yeast, and bacteria including: Aspergillus niger, Penicillium chrysogenum, $R$. minuta, $S$. cerevisiae, $P$. stipitis, $P$. fluorescens, B. subtils and E. coli species.

Antifungal and antibacterial activities of the tested polymers were determined as described before [19, 20]; the size of the resulting inhibition zone was determined in Table 4 It can be seen from the Table 4 that all the selected polyketones and copolyketone showed no significant influence antifungal activity against the selected fungi.

On the other hand, it can be clarified from the data shown in Table 4 and Figure 3 that the majority of the selected polyketones and copolyketone has a moderated antibacterial activity against Trichophyton rubrum, Bacillus cereus, Serratia marcescens, and Staphylococcus aureus. The exception for polyketones VId and VI against Trichophy ton rubrum, polyketone $\mathbf{V}$ against Aspergillus flavus, polyketone IVa against Geotrichum candidum, and polyketone $\mathbf{V}$ against Staphylococcus aureus which have no significant influences. Whereas only polyketones IVa and IVb showed a strong antibacterial activity against Trichophyton rubrum compared with the controlled values $(15,18 /$ resp.), polyketeones IVb, IVc, IVd, V showed strong antibacterial activity against Geotrichum candidum (10/21/9/8 resp.); and polyketones IVa, IVb, IVc, IVd showed strong antibacterial activity against Staphylococcus aureus (13,9/17/15 resp.), on the other hand, the rest of selected polymers and copolymers showed week significant influences.

These results indicate that the polyketones significantly inhibit the growth of microorganisms. It can be clarified from this figure that, the control culture (without polymer sample) generally exhibits maximum growth. On the other hand, the polymers sample giving different growth may be attributed to polymer structures. We believe that more work

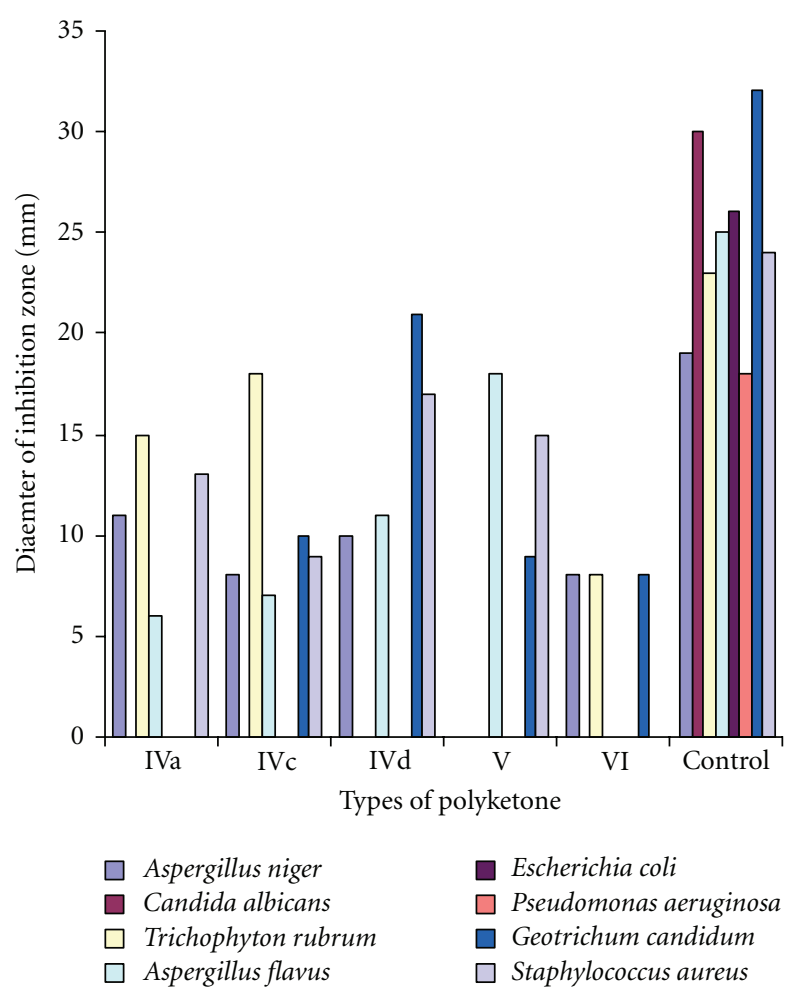

Figure 3: Effect of polyketones and copolyketones on the growth (\%) of bacteria.

is needed to identify the moiety that is most important in the different structures for higher antimicrobial activity which will be done in our next work.

\section{Conclusions}

Two novel series of unsaturated polyketones and copolyketones based on 2,7-bis furfurylidene cycloheptanone have successfully been synthesize via Friedel-Crafts reaction. Polymers properties were strongly affected by their structural differences. In general, the introduction of the flexibilizing aliphatic linkages leads to polymer of a higher solubility in NMP. X-ray diffraction analyses indicated that most of the polymers are amorphous. All the prepared polymers are highly thermally stable and thermogravimetric analyses showed that the polyketones based aliphatic chains were somewhat less thermally stable than their polymers based aromatic. All the polymers showed antimicrobial activity.

\section{References}

[1] J. M. G. Cowie, Polymer Chemistry and Physics of Modern Materials, Chapman and Hall, London, UK, 2nd edition, 1994.

[2] Seymour/Carraher's Polymer Chemistry, Marcel Dekker, New York, NY, USA, 5th edition, 2000.

[3] M. Stadlbauer, G. Eder, and H. Janeschitz-Kriegl, "Crystallization kinetics of two aliphatic polyketones," Polymer, vol. 42, no. 8, pp. 3809-3816, 2001.

[4] N. Z. Patel, J. N. Patel, R. M. Ray, and R. M. Patel, "Synthesis and biological activity of chlorinated polyketone resins," 
Angewandte Makromolekulare Chemie, vol. 192, no. 1, pp. 103$111,1991$.

[5] B. T. Patel, Y. K. Solanki, P. M. Patel, and R. M. Patel, "Synthesis, characterization and microbial behaviour of some polyketones," Research Journal of Chemistry and Environment, vol. 1, no. 1, p. 21, 1997.

[6] B. T. Patel, R. T. Patel, R. M. Patel, and K. C. Patel, "Friedelcrafts polyketones: synthesis, characterization and antimicrobial properties," Angewandte Makromolekulare Chemie, vol. 263, pp. 21-23, 1998.

[7] B. V. Patel, B. T. Patel, and R. M. Patel, "Synthesis and antimicrobial properties of friedel-crafts polyketones," Asian Journal of Chemistry, vol. 10, no. 1, pp. 126-130, 1998.

[8] R. T. Patel, Y. N. Mehta, and R. M. Patel, "Synthesis and biocidal properties of some friedel-crafts polyketones," Research Journal of Chemistry and Environment, vol. 2, no. 2, p. 29, 1998.

[9] U. S. Patel, A. K. Pandey, and R. C. Rajak, "Chaetasbolisia indica sp. nov. from India," Mycological Research, vol. 101, no. 3, pp. 335-336, 1997.

[10] D. A. Patel, B. S. Shah, and R. M. Patel, "Synthesis of some friedel-crafts resins and their antimicrobial study," Research Journal of Chemistry and Environment, vol. 2, no. 4, p. 67, 1998.

[11] B. T. Patel and R. M. Patel, "Synthesis, thermal behaviour and biological activity of chlorine containing polyketones," International Journal of Polymeric Materials, vol. 41, no. 3-4, pp. 199-206, 1998.

[12] B. P. Kuchkov, G. R. Finn, L. L. Entsova, and A. A. Mozgina, Tr. Volgogr. Gos. Med. Inst., vol. 21, p. 486, 1968.

[13] W. B. Ackart, R. L. Camp, W. L. Wheelwright, and J. S. Byck, "Antimicrobial polymers," Journal of Biomedical Materials Research, vol. 9, no. 1, pp. 55-68, 1975.

[14] V. N. Tarason and V. K. Boldasov, Voenno-Meditsinskii Zhurnal, vol. 9, no. 3, 1967.

[15] A. Vogel, Text Book of Practical Organic Chemistry, vol. 1, Pergamon, New York, NY, USA, 2nd edition, 1980.

[16] K. I. Aly, "New polymer syntheses VIII. Synthesis, characterization and morphology of new unsaturated copolyesters based on dibenzylidenecycloalkanones," Polymer International, vol. 47, no. 4, pp. 483-490, 1998.

[17] A. Tager, Physical Chemistry of Polymers, Mir Publishing, Moscow, Russia, 1972.

[18] R. J. Swedo and C. S. Marvel, "Biphenylene as a crosslinking unit in polyaromatic ether-ketone and ether-ketone-sulfone resins. XVI ," Journal of Polymer Science, vol. 17, no. 9, pp. 2815-2824, 1979.

[19] T. Namba, M. Tsunezuka, and M. Hattori, "Dental caries prevention by traditional Chinese medicines. Part II. Potent antibacterial action of magnoliae cortex extracts against Streptococcus mutans," Planta Medica, vol. 44, no. 2, pp. 100106, 1982.

[20] S. T. Pai and M. W. Platt, "Antifungal effects of Allium sativum (garlic) extract against the Aspergillus species involved in otomycosis," Letters in Applied Microbiology, vol. 20, no. 1, pp. 14-18, 1995. 

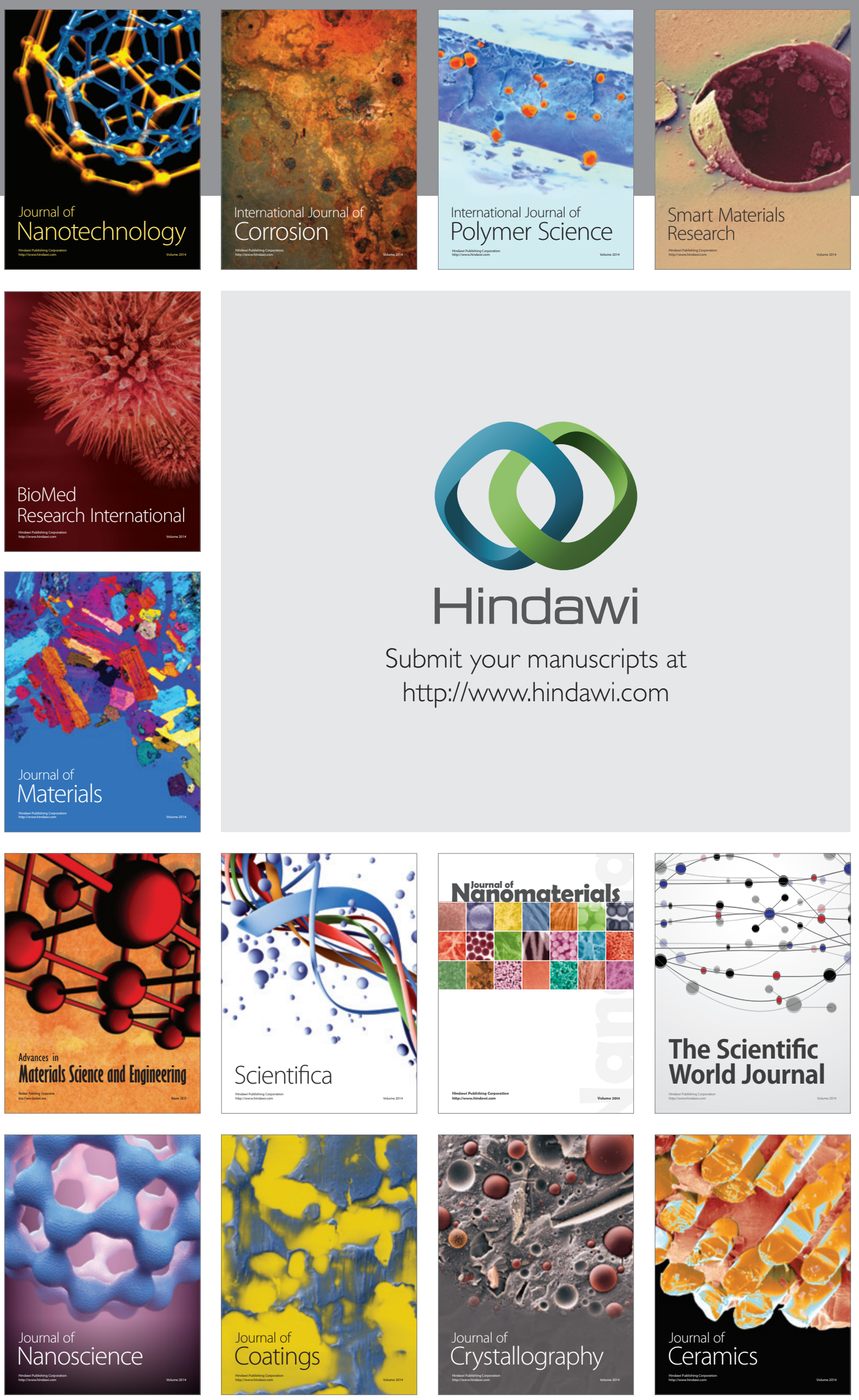

The Scientific World Journal

Submit your manuscripts at

http://www.hindawi.com

\section{World Journal}

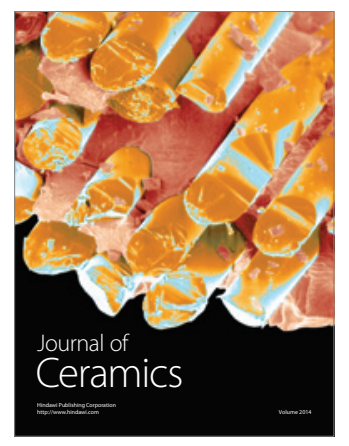

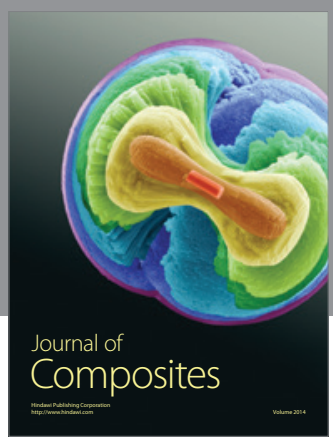
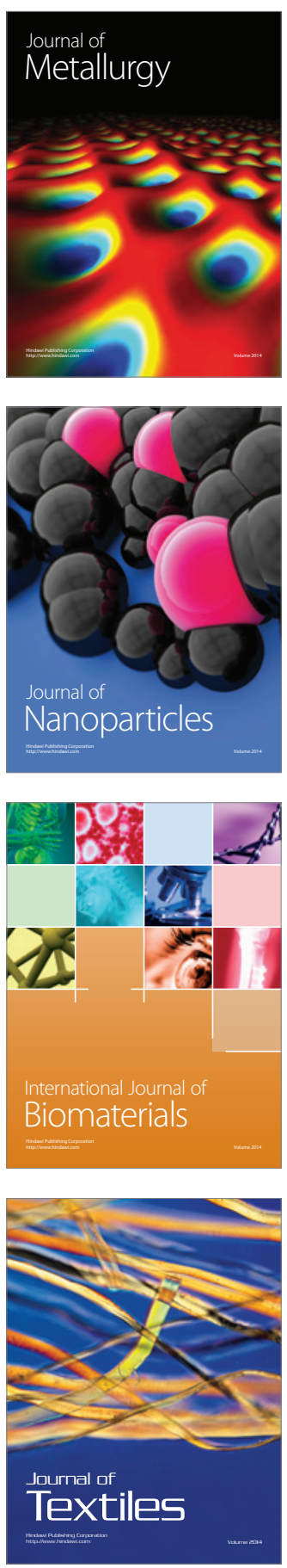